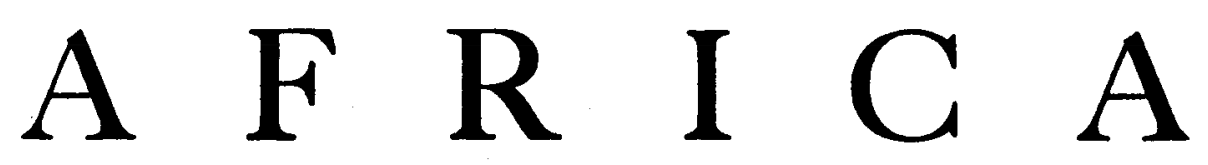

JOURNAL OF THE INTERNATIONAL AFRICAN INSTITUTE

\title{
OBITUARY
}

\section{MARCEL GRIAULE}

$\mathrm{B}$ $Y$ the death of Marcel Griaule on 25 February 1956 (recorded in the April number of $A$ frica) ethnological and African studies in France have lost an outstanding leader, and this Institute has been deprived of a most valued officer. As Consultative Director from 1948, Marcel Griaule participated with great energy and effectiveness in the work of the Institute, and was active on its behalf in securing a close and continuous liaison with official and academic bodies in France and French Africa. As a member of the Institute's Executive Council, his sincerity and personal charm gained for him the warm affection of his colleagues, while his scholarly integrity and his devotion to humanistic studies, and to ethnological research in particular, enabled him to make a distinctive and exceptionally valuable contribution to the Council's discussions.

Born in 1898 , Griaule turned his attention to ethnology after the First World War, in which he served with distinction first in the French artillery and later in the Air Force. He also saw service during the Second World War and was awarded the Croix de Guerre. His first field expedition took him to Abyssinia in 1928-9; in $1931-3$ he organized a mission of ethnographic reconnaissance from Dakar to Djibouti, during which he first encountered the peoples of the Niger bend, and in particular the Dogon of the French Sudan on whom his scientific interest, as well as his deep affection, were to be concentrated. From 1946 until his death he revisited them annually, studying all aspects of their culture and social life, from linguistics to technology, and concerning himself no less with their material welfare and spiritual well-being. But his outstanding achievement was his profound and detailed investigation of the complex ritual and elaborate symbolism which he found among this people, and his penetrating analysis of the cosmological ideas underlying it. In pursuing these studies with intense energy, he attached to himself a band of devoted collaborators, many of whom owed their initiation into African studies to his inspiration and to whom he extended his unfailing assistance and encouragement.

Griaule's earlier researches were published in a number of monographs, notably Masques dogons and Jeux dogons, both in 1938, and in numerous articles. In Dieu d'eau (1948) he gave a first brief account of Dogon cosmology in the form of a record of conversations with Ogotemmêli, an elder and priest. A later and systematic outline of

'Africa', the Journal of the International African Institute, is published by the Institute, but except where otherwise stated the writers of the articles are responsible for the opinions expressed. 
Dogon beliefs is available in English in the chapter which he contributed, in collaboration with Dr. Germaine Dieterlen, to African Worlds (1954). At the time of his death he was engaged in preparing a detailed and definitive presentation of the great mass of material collected in the course of his field studies over the past eight years; this study was to have consisted of several volumes, the first of which has been virtually completed; its publication will be eagerly awaited.

Griaule was a most effective public speaker. His sincerity and his intellectual power were equally evident in formal addresses and in discussion. He was a master of luminous exposition, of the telling phrase and the pungent rejoinder. Although his own work was largely concentrated in the specialized field which he had made peculiarly his own, he recognized and encouraged other approaches. He did much to advance ethnological research in France and to secure recognition of the importance of social studies; as Professor of Ethnology in the University of Paris from 1942 he interested himself in the training of students and in securing facilities for the pursuit of field studies; as a Conseiller of the Union Française he devoted much time and energy to furthering the harmonious development of the peoples of French West Africa.

The Institute's Executive Council at its recent meeting recorded its recognition of his great qualities and his services to scholarship, and expressed its sympathyin which all our members will wish to share-with his family and his colleagues in France.

DARYLL FORDE

\section{DAVID TAIT}

$\mathrm{T}$ is with sincere regret that we record the sudden death at Accra on 7 April 1956 of 1 Dr. David Tait. In 1949, soon after graduating from University College, London, he was appointed to a Lectureship in Anthropology in the University of the Gold Coast, where he gained the respect and warm affection of his colleagues and pupils. He was already known and appreciated among Africanists for his ethnological and linguistic field studies, and for a number of papers in which he had presented some acute analyses of the social system of the Konkomba peoples in the Northern Territories of the Gold Coast. He had recently embarked on an extended programme of research among the Dagomba. Tait's untimely death at the early age of 44 has cut short a most promising career while much of his valuable field material is still awaiting publication. It is greatly to be hoped that means may be found for making the results of his thorough and scholarly researches generally available. Our sympathy is extended to his wife and colleagues.

Dr. Tait died before he was able to correct the proofs of his article: 'The Family, Household, and Minor Lineage of the Konkomba', of which Part I appears in this number and Part II will appear in the next number of Africa. 